\title{
The Issue of Gender Discrimination in Meghalaya With Special Reference to East Khasi Hills
}

\author{
${ }^{1}$ Wangshimenla Jamir, ${ }^{2}$ A.P.Warjri, ${ }^{3}$ Iabianglang Kharbuki, \\ ${ }^{4}$ Wanshanskhe Ryndem \& ${ }^{5}$ P. Rijied Lamare \\ ${ }^{1,2,3,4}$ Department of Geography, Nagaland University, Headquaters: Lumami, Nagaland \\ ${ }^{5}$ Department of Geography, Synod College, Shillong.
}

\section{Introduction}

Gender discrimination is one of the most serious issues confronted by every culture, and country these days. The term Gender discrimination or Sexism can be described as unfair treatment of a group or a person due to their gender or sex. In theory, gender discrimination can affect both men and women, but in most cases it is women who have been at the receiving end since most cultures in the world are patriarchal, or male dominated. According to the United Nations, discrimination against women is taking place in every society, where women do not have equal opportunities as men. Even in advance and developed countries of the world, women still experience the unfairness of the 'glass ceiling', wherein they do not get promoted beyond a certain level. If women in the emancipated West and well advanced countries of the world are still continuing to struggle for justice and equal rights, one can imagine the abuse and discrimination suffered and tolerated by girl-child and women in developing countries all over the world including our own, worst still in fanatical nations like Afghanistan and many others.

Gender discrimination involve a wide range of abuses, from wives being ill-treated by their spouses, eve teasing to deadly ones such as being sold for sex trade, rape, child abuse, sex-selective abortion, infanticide, neglect, dowry deaths, honor killings and the list is inexhaustible. Till date majority of the men folks all across the globe still regard women as passive, weak and many a times merely as sexual objects. This peculiar and detrimental mindset is very much alive in almost every society including ours. With such an attitude towards them, their hope to attain gender parity such as equal pay, respect, justice, etc in the near future is still very bleak. These types of discrimination has undoubtedly affected and suppressed the potential of practically every aspect of women's lives, and has prevented them from accomplishing and delivering their full potential as normal human beings.

\section{East Khasi Hills- An overview}

East Khasi Hill district is a landscape shared by many indigenous tribes embracing a kaleidoscope of colorful, unique and rare cultures seen only in this region. The main tribal inhabitants of the district comprise the Khasis, Jaintias and the Garos. Besides these, the district is also the home of other smaller ones such as the Hajongs, Kochs, and the Rabhas (Singh, 1994; Sangma, 1998). Most of these communities are still following the age old simple traditional way of life. However with the influence of the colonial regime that came about in the $17^{\text {th }}$ century and lasted one and a half century, the district was fairly exposed to the outside world and a significant part of this has been eroded away and the people have thrived to adopt the modern lifestyle especially in the urban areas.

At present the district is also the home of many non-tribal communities. At a glance, the population of the district in 2011 was $8,24,059$ persons, scattered in the $8 \mathrm{C} \&$ RD blocks comprising of 962 villages and 8 towns of the district. The urbanization in the district is about $44.37 \%$. However Shillong, being the capital of the state caters to a population of about 3,54,325 persons in 2011. The city is the hub of all administrative, education, health, recreation, culture and a vast array of functions. The density of population is about 292 persons per sq km, and the sex ratio is abnormally in favor to females showing 1011 female per 1000 males. The average literacy rate of the district is $84.15 \%$, (male $85.26 \%$, female $84.15 \%$ ) while the differences between the urban and the rural is $87.7 \%$ and $66.8 \%$ respectively which still reflects the uneven developmental scenario within the district. The people of the district embrace many religious beliefs. However with more than 150 years of Christian missionary influence, at present the state is dominated with $70.01 \%$ Christians, $13.27 \%$ Hindus, $11.52 \%$ other religion and persuasion, $4.49 \%$ Muslims, and the rest comprises of Buddhist, Sikhs, Jains and others.

Comparing to other districts of the state, East Khasi hills is fairly more advance in all aspects in term of the developmental infrastructures. Hence Shillong city is a hometown of a thriving multi-ethnic society portraying a truly cosmopolitan image. Yet the matrilineal culture especially of the dominant society-The 
Khasis, is still surviving where considerable, social concessions such as authority, title, inheritance, residence after marriage and succession are traced through the female line, though the political and administrative affairs of the society are generally left to the men folks to take care of. One may presume that things are better of here for the women. Many would also expect that perhaps these fortunate women of Meghalaya who enjoys special social status can even provide the much needed hope in setting an example to bring about a change in attitude towards women into a positive, acceptable and respectable one throughout the world.

No doubt, with the passage of time, the district has experienced fast growth in all spheres. However on one hand, one can see positive changes like improvement in modern infrastructure and amenities etc. Yet on the other the reality is rather different as when one examine closely can perceive the gamut of negative changes that have brought down the socio-cultural values of the entire society, especially the degrading moral ethics. One of the most disgusting menaces experienced and reported regularly throughout the state these days, is the increasing crime and discrimination against women like those mentioned above. The society as a whole including the members of the National Commission for Women (NCW) expressed concern over increasing crimes against women in Meghalaya, as many do not expect that crime graph on violence against women should rise so high in a matrilineal society of Meghalaya.

Hence after a brief insight about the social setting of the district, one can imagine the challenges to be encountered in these types of studies. However it should be understood that these can also be the clues that can help in unraveling the mystery of all types of problems pertaining to our society in the East Khasi Hill District of Meghalaya.

\section{Objective}

The study is definitely a very wide and sensitive one. However it is impossible to address all aspects relating to gender discrimination in a limited paper such as this. So the objective of the present study will confine only on the following areas:-

1. To study and highlight the trend of crime rate and gender discrimination in East Khasi hills district of Meghalaya.

2. To find out the root cause of crimes and discrimination against women in East Khasi hills.

3. To suggest relevant remedy to encounter and mitigate such crimes.

\section{Data source and Methodology}

The study is based upon various aspects avail from both primary and secondary sources. The whole study is based on field investigation, interaction with the people, experts in social studies, NGOs, Police Department etc. It is also based on empirical facts and figures obtained through various sources. All the data, evidences, and other information collected are represented and analyzed with the aid of appropriate techniques and relevant comments, remedies and suggestions are put forth accordingly for consideration and necessary action of all concern.

\section{The trend of crime against women-The analyzes}

Gender discrimination is as old as humanity itself. No one really know for sure how this evil came to be a part of human social life, yet as of now the detrimental impact on any society has been far reaching. It is true that as per any religion's doctrine, women should be submissive to men. The same is even true in the indigenous matrilineal Khasi society where women are generally a respectable lot, but due to her physical weakness she is considered as a one by twelve of a man and therefore she should be a little less than a man. The prevailing social structure does clearly indicate the ground reality.

However nowhere in any religion or even in the social setting of the Khasis or any other society that discrimination against women is encouraged at any point of time. In fact women of all societies are usually protected by their male counterpart. Yet perhaps because of the general passiveness of the woman that encourages the stronger masculine and aggressive men to develop an ever growing macho mindset and women are therefore seen as weaklings and objects for sexual lust thus giving rise to all kinds of gender discrimination, violence and biasness against the fairer sex.

Concerning the present social environment status of the state of Meghalaya as a whole and East Khasi hills district in particular, the fast growth of population has put pressure on the various aspects of the region like overcrowding, congestion, unemployment problem, problems arising at household level, in the society and so on which has become more of a hindrance for the state as a whole. Every effort has been put in by the government and the society at large to find ways and means to overcome these crises. Recently many types of economic activities have been encouraged and introduced. Alongside all these efforts put forward by the Government for the well being of the people, on the other side problems are arising in the society like rape, molestation, kidnapping/abduction, eve teasing, murder for dowry, attempt to commit murder, dowry death, attempt to 
commit suicide, cruelty by husband or relatives, abetment of suicides, importing of girls, immoral trafficking and so on which deteriorate the social environment, adding more to the constraints.

Meghalaya has witnessed tremendous increase of crimes in the last ten years. According to official data, the number of crimes against women was 66 in 2001, 71 in 2002 and 69 in 2003. It rose to 113 in 2004 and 131 in 2005. The crime graph escalated further in 2006 with 176 cases. The number of cases was 172 in 2007 , increases to 208 in 2008, 237 in 2009, 261 in 2010 and 269 in 2011 and 255 in 2012. Statistics provided by the Police department have revealed staggering figures of rape cases reported in the State, especially rape on minors which are increasingly at an alarming rate.

\begin{tabular}{|l|l|l|l|l|l|l|l|l|l|l|l|l|l|l|}
\hline \multicolumn{1}{|l|}{ CRIME AGAINST WOMEN CASES REPORTED IN MEGHALAY DURING 2001-2012 } \\
\hline Crime Head & $\mathbf{2 0 0 1}$ & $\mathbf{2 0 0 2}$ & $\mathbf{2 0 0 3}$ & $\mathbf{2 0 0 4}$ & $\mathbf{2 0 0 5}$ & $\mathbf{2 0 0 6}$ & $\mathbf{2 0 0 7}$ & $\mathbf{2 0 0 8}$ & $\mathbf{2 0 0 9}$ & $\mathbf{2 0 1 0}$ & $\mathbf{2 0 1 1}$ & $\mathbf{2 0 1 2}$ \\
\hline Rape & 26 & 38 & 40 & 54 & 63 & 74 & 82 & 88 & 112 & 149 & 130 & 164 \\
\hline $\begin{array}{l}\text { Kidnapping \& } \\
\text { Abduction of } \\
\text { Women \& Girls }\end{array}$ & 11 & 10 & 10 & 18 & 19 & 25 & 22 & 25 & 26 & 37 & 37 & 24 \\
\hline Dowry death & 0 & 0 & 0 & 2 & 1 & 6 & 2 & 2 & 0 & 0 & 1 & 1 \\
\hline Molestation & 25 & 23 & 13 & 34 & 44 & 57 & 45 & 54 & 72 & 48 & 74 & 43 \\
\hline Sexual harrassment & 0 & 0 & 1 & 0 & 0 & 0 & 1 & 4 & 1 & 0 & 1 & 0 \\
\hline $\begin{array}{l}\text { Cruelty by husband } \\
\text { or other relatives }\end{array}$ & 4 & 0 & 4 & 5 & 3 & 13 & 19 & 32 & 24 & 24 & 21 & 16 \\
\hline Importation of Girls & 0 & 0 & 0 & 0 & 0 & 0 & 0 & 0 & 1 & 0 & 3 & 0 \\
\hline $\begin{array}{l}\text { Immoral Traffic } \\
\text { (Prevention) Act }\end{array}$ & 0 & 0 & 1 & 0 & 1 & 1 & 1 & 3 & 1 & 3 & 2 & 7 \\
\hline $\begin{array}{l}\text { Dowry Prohibition } \\
\text { Act }\end{array}$ & 0 & 0 & 0 & 0 & 0 & 0 & 0 & 0 & 0 & 0 & 0 & 0 \\
\hline $\begin{array}{l}\text { Total Crimes } \\
\text { against Women }\end{array}$ & $\mathbf{6 6}$ & $\mathbf{7 1}$ & $\mathbf{6 9}$ & $\mathbf{1 1 3}$ & $\mathbf{1 3 1}$ & $\mathbf{1 7 6}$ & $\mathbf{1 7 2}$ & $\mathbf{2 0 8}$ & $\mathbf{2 3 7}$ & $\mathbf{2 6 1}$ & $\mathbf{2 6 9}$ & $\mathbf{2 5 5}$ \\
\hline
\end{tabular}

Source: Meghalaya Police

Meghalaya is a state that boasts of women empowerment where women enjoy higher social status and the advantage of inheriting property and moreover are seen at the forefront in domestic as well as public life. Yet with all these social status that the women of the state are enjoying, the society is still experiencing the degradation of the social status of women and they are now reduced to just as sexual objects. The above escalating facts and figures reveal that the matrilineal society no longer guarantees dignity and safety to women.

Rape, molestation, abduction and kidnapping of girls and women, cruelty by husband and relatives are the most common type of crime against women in the state. The most rampant of all the type of crimes confront by the women in the state is rape as it is recorded the highest. The crime chart would be higher had the occurrence of all crimes been reported, as most of the victims and the victims family hesitate to approach the concern authority when face with such circumstances as they are feared that it will cause disgrace to the family, social stigma and threats that may come from the perpetrator.

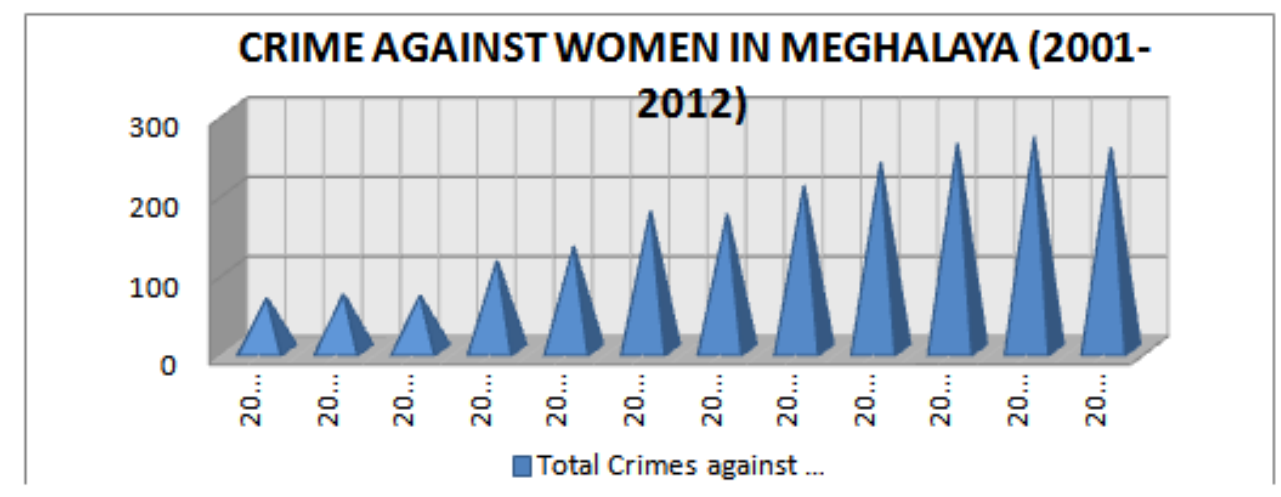

Source: Meghalaya Police

Moreover, according to the survey obtain through statistics and reports from daily news papers and magazine have revealed that East Khasi Hills District have the maximum cases of crimes in the State and dominates every form of crimes against women in the recent years. The District leads all other Districts with $39 \%$ in $2008,47 \%$ in $2009,28 \%$ in $2010,37 \%$ in 2011 and $36 \%$ in 2012. 


\begin{tabular}{|l|l|l|l|l|l|l|l|l|l|l|l|}
\hline \multicolumn{1}{|c|}{ DISTRICTWISE NUMBER OF CASES REGISTERED AGAINST WOMEN DURING THE YEAR 2001-2011 } \\
\hline District & $\mathbf{2 0 0 1}$ & $\mathbf{2 0 0 2}$ & $\mathbf{2 0 0 3}$ & $\mathbf{2 0 0 4}$ & $\mathbf{2 0 0 5}$ & $\mathbf{2 0 0 6}$ & $\mathbf{2 0 0 7}$ & $\mathbf{2 0 0 8}$ & $\mathbf{2 0 0 9}$ & $\mathbf{2 0 1 0}$ & $\mathbf{2 0 1 1}$ \\
\hline EAST KHASI HILLS & 21 & 28 & 29 & 48 & 48 & 91 & 69 & 81 & 76 & 71 & 86 \\
\hline WEST KHASI HILLS & 6 & 10 & 6 & 12 & 19 & 6 & 10 & 21 & 24 & 42 & 30 \\
\hline JAINTIA HILLS & 14 & 8 & 11 & 17 & 23 & 23 & 33 & 30 & 33 & 38 & 38 \\
\hline RIBHOI DISTRICT & 6 & 7 & 7 & 7 & 16 & 14 & 21 & 9 & 34 & 32 & 24 \\
\hline WEST GARO HILLS & 13 & 13 & 11 & 27 & 19 & 30 & 31 & 51 & 56 & 59 & 42 \\
\hline EAST GARO HILLS & 4 & 3 & 1 & 1 & 4 & 11 & 7 & 4 & 11 & 11 & 5 \\
\hline SOUTH GARO HILLS & 2 & 2 & 4 & 1 & 2 & 1 & 1 & 2 & 3 & 8 & 8 \\
\hline Total Crimes against Women & $\mathbf{6 6}$ & $\mathbf{7 1}$ & $\mathbf{6 9}$ & $\mathbf{1 1 3}$ & $\mathbf{1 3 1}$ & $\mathbf{1 7 6}$ & $\mathbf{1 7 2}$ & $\mathbf{1 9 8}$ & $\mathbf{2 3 7}$ & $\mathbf{2 6 1}$ & $\mathbf{2 3 3}$ \\
\hline
\end{tabular}

Source: Meghalaya Police.

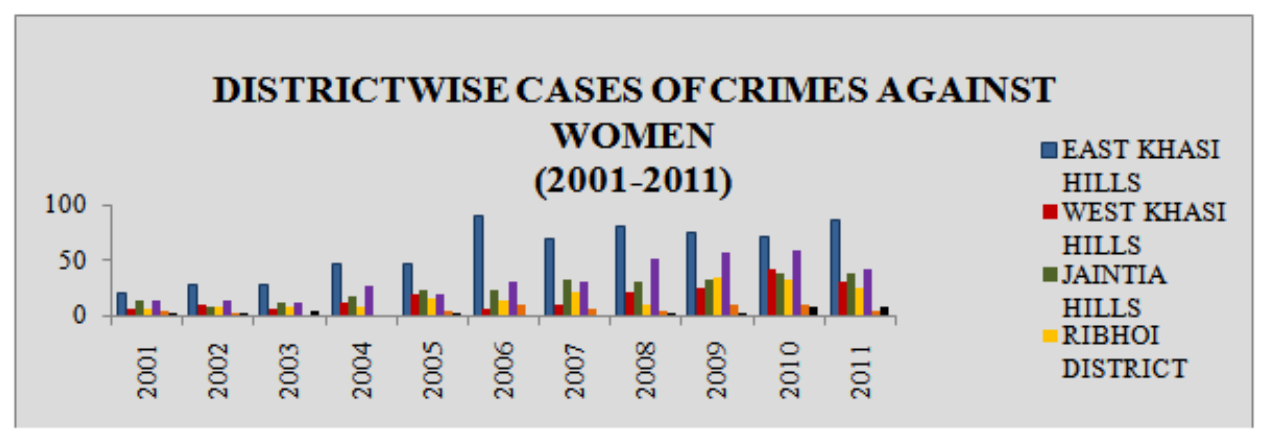

East Khasi hills district where Shillong, the capital of the state is located is the center of all forms of activities ranging from social, political, economic etc. It is here that we see the largest number of population from all sorts of socio-cultural background congregate. It is also the center which attracts huge number of migrants from all over the state as well as from neighboring states and countries. Thus, as reveal in the statistics, it is definitely the hub of all kinds of social evils and crimes in the state.

\begin{tabular}{|l|l|l|l|l|l|l|l|l|}
\hline \multicolumn{7}{|c|}{ DISTRICTWISE NUMBER OF CASES REGISTERED AGAINST WOMEN (2011) } \\
\hline Crime Head & EGH & EKH & JH & RB & SGH & WGH & WKH & TOTAL \\
\hline Rape & 3 & 43 & 32 & 12 & 3 & 12 & 19 & 124 \\
\hline Molestation (Outraging modesty) & 2 & 23 & 6 & 6 & 1 & 13 & 11 & 62 \\
\hline Kidnapping \& Abduction of women & & 7 & & 5 & 2 & 8 & & 22 \\
\hline Eveteasing (Insulting modesty) & & & & & 1 & 1 & & 2 \\
\hline Murder for dowry & 0 & 0 & 0 & 0 & 0 & 0 & 0 & 0 \\
\hline Attempt to commit murder for dowry & 0 & 0 & 0 & 0 & 0 & 0 & 0 & 0 \\
\hline Dowry Death & 0 & 0 & 0 & 0 & 0 & 1 & & 1 \\
\hline $\begin{array}{l}\text { Attempt to commit suicide for dowry by } \\
\text { burning }\end{array}$ & 0 & 0 & 0 & 0 & 0 & 0 & 0 & 0 \\
\hline Cruelty by husband or other relatives & 0 & 10 & 0 & 1 & 1 & 6 & 0 & 18 \\
\hline Abetment of suicide & 0 & 1 & 0 & 0 & 0 & 1 & 0 & 2 \\
\hline Importing of girls & 0 & 0 & 0 & 0 & 0 & 0 & 0 & 0 \\
\hline Immorall Traffic Prevention Act & 0 & 2 & 0 & 0 & 0 & 0 & 0 & 2 \\
\hline $\begin{array}{l}\text { Indecent representation of women } \\
\text { (Prohibition)Act 1986 }\end{array}$ & 0 & 0 & 0 & 0 & 0 & 0 & 0 & 0 \\
\hline Total Crimes against Women & $\mathbf{5}$ & $\mathbf{8 6}$ & $\mathbf{3 8}$ & $\mathbf{2 4}$ & $\mathbf{8}$ & $\mathbf{4 2}$ & $\mathbf{3 0}$ & $\mathbf{2 3 3}$ \\
\hline
\end{tabular}

Source: Meghalaya Police 


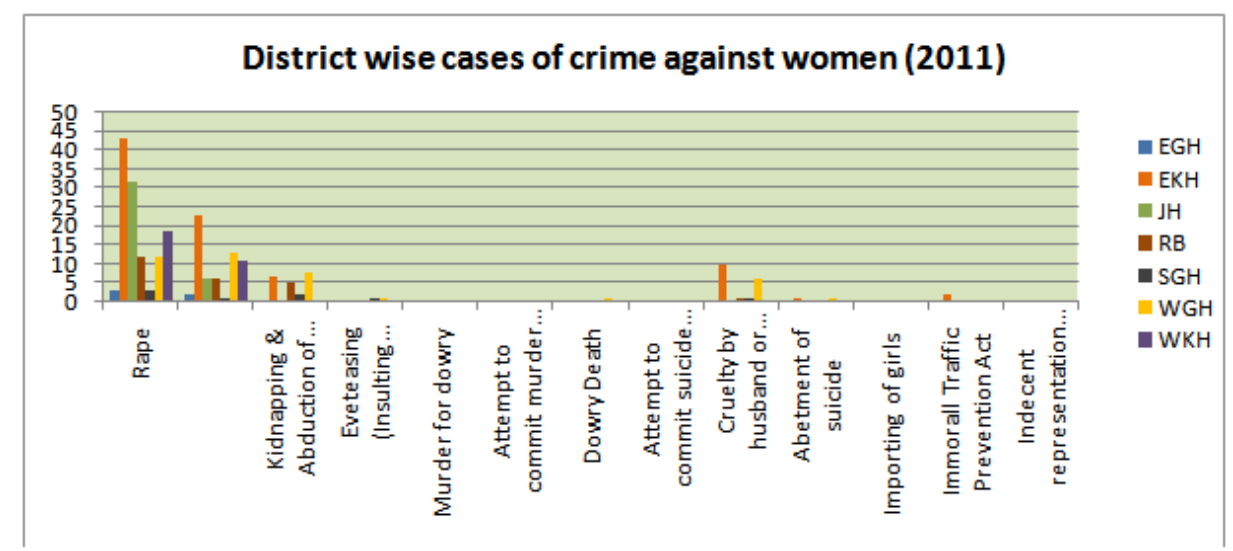

Source: Meghalaya Police

As mentioned earlier, the most committed crime in the district is rape case. The number of rape cases is leading the other types of crime followed by molestation and cruelty by husbands or relatives. The concern authority such as the Police department of the district admits the fact that rape cases especially on minors is growing at an alarming rate. Moreover, it is evident from the above facts that at least one rape case is reported on a weekly basis in the district. If such social evils are experienced in a society where a matrilineal system is followed, one can imagine the events of crimes and violence against women in societies elsewhere.

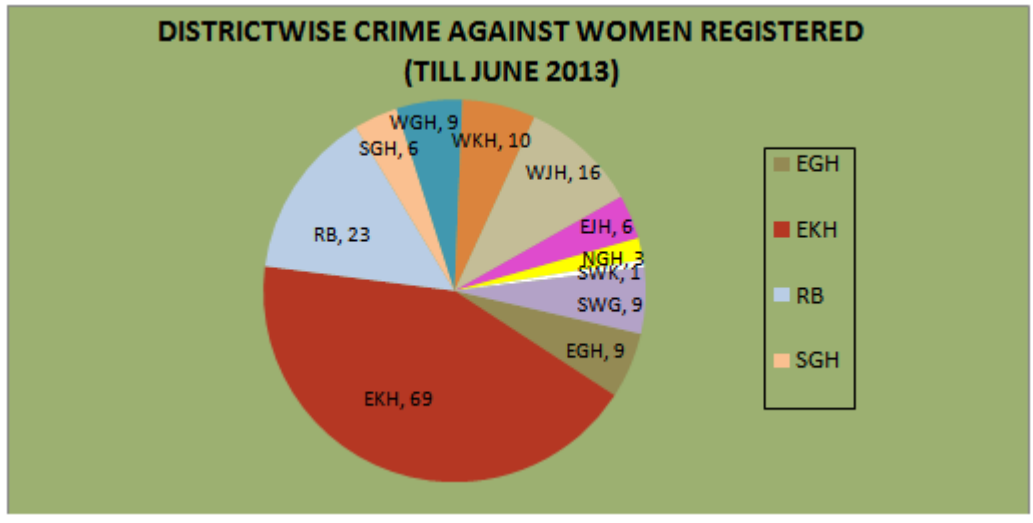

Source: Meghalaya Police

The state of Meghalaya in general and East Khasi hills district in particular, have gone through a lot of transformation in various aspects in the recent decades. No doubt growth and development in terms of social, economic, political, educational, health etc. has been tremendous. But on the other hand, breakdown in the socio-cultural values in our society is rising to such an extent that the negative impact it has incurred on the overall welfare of the state has become too hard to be ignored.

Therefore, considering the above truth reveals the fact that crimes and violence against women are issues of great concern for our own society. To get rid of these social evils is not an easy task, when evilness has deeply affected the very conscience of the perpetrators not sparing the weak and innocent ones of the society.

\section{Factors fueling the increasing crime against women}

While examining about the root cause of increasing rate of crimes against women across the

State in general and East Khasi Hills District in particular, it is evident that there are numerable factors that fuel the growth of all these social evils which result in the overall degrading of the well being of the state and thus require serious attention by all concerns in the society.

As mentioned earlier, women of the matrilineal state of Meghalaya are envied for their freedom and security that their other counterparts in the rest of the country could not avail. The concept of matrilineal system does reflect the favorable rights and status for women in their society and therefore it is hard to believe that they are instead the ones who are being discriminated. From the above reports it is evident that their life is not at all free from violence for in recent decades, the issues of crime against women are being highlighted almost on a daily basis.

Every year an increasing number of crimes against women were reported with the Police Department. The crime graph should be higher than the one mentioned above as many more violations are not reported for many reasons. It is learnt that most victims prefer to maintain the issue under cover to avoid disgraceful 
feelings. This way of thinking is very common in our society. Therefore addressing these issues have been difficult for concern authorities such as the Police and the court of law to deliver appropriate justice due to the reluctance of the victims themselves to take the fight against the perpetrators head on.

Amongst all the districts of Meghalaya, crimes against women is more rampant in the East Khasi hills district perhaps due the concentration of a larger population comprising of people belonging to different sociocultural background. The in migration of people from elsewhere especially the exodus of young people from rural areas in search better livelihood and living facilities in the city has also compounded the problem.

One of the major reasons concerning crime against women is alcoholism which is very common in our society. It is a fact that once a person gets intoxicated, it encourages the individual to indulge in all sorts of misbehavior which often culminate into violence and crimes against women. When such cases occur in a society, it is sad to note that usually the durbar or local authority take up the matter only when the damage is done and has become a nuisance for the village or the locality as a whole.

Despite being a matrilineal state, Meghalaya is facing with unusual rise in crimes against women mainly due to lack of enforcement of prevailing laws that protect women. Thus the conviction and punishment rate for rape cases as of now is very low. One of the reasons for the backlog of pending trials is the usual lackadaisical nature of the court which often delays the delivery of verdict against the perpetrators thus encouraging the increase of such crimes in the district and all across the state as a whole.

Most of the victims of crimes especially rape victims belong to a family of lower income group where both parents are bread earners. It is sad to note that even in such vulnerable families; the perpetrator is usually well acquainted to the families of the victims.

The lack of proper knowledge and awareness among women is also another reason that they are reluctant to approach concern authorities as they presume that the matter may involve a lot of complications and expenditure.

One cannot deny the fact that the present generation are greatly under the influence of outside cultures (especially the western) communicated to our society through cinema, television, the internet, easy access to electronic media and various other mediums which pollute the minds of young people as well as adults. It is also observed that because of such easy access to these social facilities, resulting in a high tendency especially among girls of younger age group to be captivated by modern western trend and lifestyle that invite and encourage more perverted mindset thus encouraging the growing occurrences of such crimes and violence in our society.

One should be aware of the negative influence of print and electronic media now a day, in the form of advertisement linked with sexual related information published on a regular basis that attract the attention of many and not appropriate especially for the younger generations.

Inadequate sex awareness programmes amongst the younger generation in educational institutions and in families is perhaps another factor that has increase the problem due to lack of knowledge concerning these social issues resulting in the deterioration of the wellbeing and security of the entire society.

Behind all these social evils and taboos perhaps the most telling cause is the lack of counseling at home, especially those families where both parents are too busy fulfilling other necessities of life. It is perhaps the order of the day that parents has failed in their role to offer moral values to their children. This has lead to the erosion of the vital socio-cultural fabric and moral ethics further accelerating the growth of crime and gender discrimination.

Therefore at this juncture when everyone in the society are so much concern about environmental degradation, everyone of us should not forget and ignore the most dangerous pollution confronted by our society these days and that is the inner pollution or mind pollution that has threaten the dignity and integrity of our society to a great extend.

\section{Suggestion of remedy}

Crime against women is a sign of social malfunction and problems arising out of psycho-spiritual dilemma. As such perpetrations are criminal offences and beyond the preview of ordinary citizens like us to deal with, however it is suggested that competent authorities should adopt stringent and appropriate steps against the perpetrators as per the law of the land befitting the nature of the crime. No doubt the Government of Meghalaya on it part has taken various steps to tackle the menace. One also cannot ignore the role of the NGO's and other organization of the society to curb these social evils which has degraded the well being of our entire society. The Police Department of the State has left no stone unturned on their part to mitigate such problems and it is a welcome effort from the government for setting up of women police stations in all the headquarters of the seven districts to monitor and address this menace. The setting up of special court to try cases relating to rape is also a commendable effort of the judicial authorities.

The August 30, 2012 notified the Meghalaya Victim Compensation Scheme 2011 whereby Rs.50, 000 would be provided for maximum limit of compensation for rape victims and Rs.25000 for injuries causing 
severe mental agony for the victim is also a step in the right direction that should be appreciated. None the less the spirit of the International Women's Day 2013 on "The Gender Agenda: Gaining momentum." including the UN theme for International women's Day 2013 which pledged "A Promise is a promise: Time for action to end violence against women", should not lose power and its message should be spread to each and every society and into every family. In order to overcome these evils in our society, it is stressed that it should start from home, where parents should be serious enough to listen and to be aware about the daily encounters of their children with the outside world especially to their complaint about any undue advantage infringe upon them. Crimes against women cannot be stopped by the Police alone nor do NGO's and other organizations also cannot reduce the problem if the society at large is ignoring the same. Therefore it is sincerely believe that it is only a collective responsibility that can eradicate such menace from our society.

\section{Conclusion}

To conclude, the study has no doubt revealed the gamut of gender discrimination and its impact on the society of East Khasi hills district including the state as a whole. The study has also revealed the growing trend of this menace and has highlighted the factors responsible for its growth which reflect the problems and mental trauma encountered by the victims after such discriminations have been perpetrated on them. It is understood from here that the only solution to this problem is sustain collective fight to be participate by the society as a whole. Hence the study is an important wakeup call and an eye opener for all especially about our inherent weakness and placidness towards these ugly problems which undermine the very dignity and integrity of our society. Therefore it is important to remind ourselves to be wary and not to be complacent with these disgusting crimes and to compromise the safety and security of the society at large.

\section{References}

Books

[1]. Criminological Theories- Introduction and Evaluation, Ronald L. Akers (1999), second edition, Fitsroy Dearborn Publishers, 919 North Michigan Avenue Chicago, IL 60611, USA.

[2]. Gazetteer of India - Meghalaya, District Gazetteers Khasi Hills District (1991), edited by I.M.Simon, published by Directorate of Arts and Culture District Gazetteers, Meghalaya, Shillong.

[3]. Geography of Crime- Assam, Kalidas Sarma (2010), Eastern Book House Publishers (India), 136, M.N. Road, Panbazar Guwahati781001, India.

[4]. Meghalaya Past and Present H.G.Joshi (2004), Mittal Publications, A-110 Mohan Garden, New Delhi-110059, India.

[5]. Pre-History of Meghalaya and Social Formation in Khasi-Jaintia History (1996), Published by Directorate of Arts and Culture, State Museum Branch, Meghalaya, Shillong.

[6]. Support Services to counter 'Violence against Women' in Meghalaya- A Resource Directory (2003), Published by North East Network, Shillong. Meghalaya.

[7]. The Protection of Women from Domestic Violence Act, 2005, Bare Act, Printed and published by Pioneers printers Seth Gali, Agra-282003, India.

Articles

[8]. Sexism-Gender Discrimination, Rita Putatunda, published 3.12.2008.

News Paper and Websites

[9]. Meghalaya Police.

[10]. The Meghalaya Guardian Daily Newspaper.

[11]. The Shillong Times Daily Newspaper. 